\title{
Can Food Supplement Produced from Apilarnil be an Alternative to Testosterone Replacement Therapy?
}

\section{Apilarnil Gıda Takviyesi Testosteron Yerine Koyma Tedavisine Alternatif Olabilir mi?}

\author{
Review Article
}

\section{Babür Erdem ${ }^{1,2 *}$, Aslı Özkök ${ }^{3}$}

'Department of Biological Sciences, Middle East Technical University, Ankara, Turkey. ${ }^{2}$ Vitaliter Natural Sciences and Engineering R\&D Ltd, ODTÜ Teknokent, Ankara, Turkey. ${ }^{3}$ Bee and Bee Products Applications and Research Center (HARÜM), Hacettepe Univesity, Beytepe, Ankara, Turkey.

\section{A B S TR AC T}

\begin{abstract}
A pilarnil is male honey bee (Apis mellifera) brood homogenate, firstly used on elders have psychotic, Aneurodegenerative or sexual disorders in Romania by Nicola lliesu in 1980. It has high nutritional value and a cheap source of biologically active substances. It consists of water (65-75\%), proteins (9-12\%), carbohydrates (6-12\%), fatty acids and lipids (3.5-8\%), minerals $\mathrm{K}, \mathrm{Na}, \mathrm{Ca}, \mathrm{Mg}(1-1.5 \%)$, essential amino acids (threonine, leucine, isoleucine, methionine) and also it is rich in sex hormones such as testosterone, prolactin, progesterone and estradiol. Some defined chemicals in lipid portion and hormones are included in Apilarnil should be responsible by androgenic effect. So, it may enhance the androgenic activity for patients with androgen deficiency syndrome. Lower androgenic activity named as androgen deficiency syndrome. It causes reduced growth of penis end testes in early ages, failure to go through full normal puberty, gynaecomastia, poor development of facial, body or pubic hair and voice does not deepen in early teenagers, mood changes, reduced muscle strength, increased body fat, decreased libido, difficulty getting and keeping erections, low semen volume and gynaecomastia in adults. In this article, Apilarnil having an androgenic content and whether or not it is effective for the androgen deficiency syndrome has been prepared and interpreted by compiling studies on Apilarnil in the literature.
\end{abstract}

\section{Key Words}

Androgenic effect, apilarnil, Apis mellifera, testosterone.

\section{öz}

\begin{abstract}
A pilarnil, ilk olarak Nicola Iliesu tarafından 1980 yılında Romanya'daki psikotik, nörodejeneratif ve cinsel rahatsızlıklara sahip olan yaşlılarda kullanılan erkek bal arısı (Apis mellifera) homojenatıdır. Yüksek besin değerine sahip olup ucuz bir biyolojik aktif madde kaynağıdır. İçeriğinde su (\%65-75), proteinler (\%912), karbohidratlar (\%6-12), yağ asitleri ve lipitler (\%3,5-8) K, Na, Ca, Mg mineralleri (\%1-1,5), amino asitler (treonin, Iösin, izolösin, metiyonin) ve ayrıca testosteron, prolaktin, progesteron ve östradiol gibi cinsiyet hormonlarınca zengindir. Apilarnilin lipid kısmında tanımlanan bazı kimyasallar ve hormonlar androjenik etki oluşturabilmektedir. Androjen eksikliği sendromu yaşayan hastalarda Apilarnil, androjen artışı sağlayabilir. Düşük androjenik aktivite, androjen eksikliği sendromu olarak adlandırılmaktadır. Androjen eksikliği sendromu, erken yaşlarda penis ve testislerin gelişiminin azalmasına neden olmakta ve ergenliği engellemektedir. Gençlerde jinekomasti, yüz, vücut ya da kasık tüyleri ile ses gelişiminde zayıflıklara sebep olmakta, yetişkinlerde ise ruh hali değişiklikleri, kas kuvveti azalması, vücut yağında artış, libido azalması, ereksiyon zorluğu, düşük sperm hacmi ve jinekomasti gibi sorunlara neden olmaktadır. Bu makalede androjenik içeriğe sahip olan Apilarnilin androjen eksikliği sendromuna etkili olup olmadığı ve kullanılabileceği alanlar, literatürdeki Apilarnil ile ilgili çalışmalar derlenerek hazırlanmış ve yorumlanmıştır.
\end{abstract}

\section{Anahtar Kelimeler}

Androjenik etki, apilarnil, Apis mellifera, testosteron.

Article History: Received: June 10, 2017; Revised: Aug 12, 2017; Accepted: Sep 20, 2017; Available Online: Dec 25, 2017.

DOI: 10.15671/HJBC.2018.207

Correspondence to: B. Erdem, Department of Biological Sciences, Middle East Technical University, Ankara, Turkey. 


\section{INTRODUCTION}

A pilarnil is male honey bee brood homogenate, firstly used on elders have psychotic, neurodegenerative or sexual disorders in Romania by Nicola Iliesu in 1980. Name of APILARNIL was created by the Romanian scientist, API from latin name of bees (Apis), LAR from larvae and his initials name NIL (Nicolae Iliesiu). It is obtained by triturating of the drone larvae harvested in special conditions, in the seventh day of their life [1]. It is a homogenous and milky substances, with yellowish grey color and sour taste [2].

Apilarnil has high nutritional value and is a cheap source of biologically active substances. It consists of water $(65-75 \%)$, proteins (9-12\%), carbohydrates (6-12\%), fatty acids and lipids (3.5-8\%), minerals $\mathrm{K}, \mathrm{Na}, \mathrm{Ca}, \mathrm{Mg}(1-1.5 \%)$, essential amino acids (threonine, leucine, isoleucine, methionine) [15] and also it is rich in sex hormones such as testosterone, prolactin, progesterone and estradiol. So, it has many strengthening effects on male seconder sex characteristics. $[2,6,7]$. Some of the recent researches indicates the androgenic effect of Apilarnil and focuses on the source of the androgenic effect. Some defined chemicals in lipid portion and hormones are included in Apilarnil should be responsible by androgenic effect.

Lower androgenic activity named as androgen deficiency syndrome. It causes reduced growth of penis end testes in early ages, failure to go through full normal puberty, gynaecomastia, poor development of facial, body or pubic hair and voice does not deepen in early teenagers, mood changes, reduced muscle strength, increased body fat, decreased libido, difficulty getting and keeping erections, low semen volume and gynaecomastia in adults. Androgen deficiency syndrome can be caused by problems in testes, pituitary or hypothalamus $[8,9]$. In addition, testosterone deficiency syndrome is deficiency of serum testosterone or loss of sensitivity of receptors to testosterone, mainly observed in late ages, also named as andropause [10]. Both syndromes are cured by testosterone replacement therapy. Testosterone replacement therapy restores the testosterone levels in normal range via injections, skin patches or creams include synthetic forms of testosterone. However, testosterone replacement therapy has some possible side effects as weight gain, mild acne, increased aggression and gynaecomastia [8].

In this article, Apilarnil having an androgenic content and whether or not it is effective for the androgen deficiency syndrome has been prepared and interpreted by compiling studies on Apilarnil in the literature.

In 2011, Yücel et al., [11] performed a simple experiment on male broilers to determine androgenic effect of male honey bee brood. They fed 17 day old chicks with Apilarnil ( $4 \mathrm{~g} /$ day) along 21 days and measured the comb size, as seconder sex characteristics. At the end of the experiment, it was determined that the experiment group have bigger combs then controls [11]. Altan is a participant of the same research group deepened the research in 2013 [12]. She examines both comb and testes size and fearful behavior in broilers with oral administration of different dosage of Apilarnil. Also, she measures the testosterone and cholesterol levels in blood. Administration of high dosage Apilarnil ( $7.5 \mathrm{~g} /$ day) increases the comb and testes sizes and testosterone level very significantly, also statistically significant decreasing observes in the fearful behavior and total cholesterol level [12]. These pioneer researches indicate the androgenic effect of Apilarnil.

A more comprehensive research was carried out by Adrienn Seres in 2014 [13]. In the PhD. thesis of Seres, both estrogenic and androgenic effect of Apilarnil was investigated [13]. Firstly, to determine the estrogenic activity, Apilarnil $(570 \mathrm{mg} / \mathrm{kg} /$ day), Apilarnil + ICl 182.780 (estrogenic antagonist), 17b-estradiol and 17b-estradiol + ICl 182.780 combinations were applied to rats. Effects of the combinations were investigated via RT-PCR and Western Blot Analysis. C3 protein expression has been reported to be a molecular marker of estrogenic activity and both Apilarnil or 17b-estradiol application significantly increases the C3 mRNA level and C3 protein yields. Usage of estrogenic antagonist $(\mathrm{ICl} 182.780)$ as a control, reduces the level of $\mathrm{C} 3$ synthesis in uterus. Also, she determines the active substances in Apilarnil, responsible from estrogenic effect, used with bioactivity-guided fractionation of Apilarnil with column chromatography and high-resolution MS and NMR analyses. Thus, E-dec-2-enedioic acid 
determined as active substance in Apilarnil for estrogenic effect [14]. Secondly, similar experimental strategy was used for to determine androgenic effect on male rats. Apilarnil ( $110 \mathrm{mg} / \mathrm{kg} /$ day), testosterone, flutamide (non-steroidal antiandrogen) and their combinations applied on castrated rats. Apilarnil significantly increases the plasma testosterone level, weight of penis glans and seminal vesicle. In the control groups (both false control and flutamide applied group) there was no significant increases observed. Also, the prostatic mRNA and protein expression of Spot14-like androgen-inducible protein (SLAP) are also examined with RT-PCR and Western Blot Analysis. Thus, Apilarnil significantly increases the expression of Spot14-like androgeninducible protein (SLAP). Again, she determines the active substances using with bioactivity-guided fractionation and GC-MS and NMR spectroscopic investigations. As a result, two fatty acid esters, methyl palmitate and methyl oleate is identified as possible active substances in Apilarnil, have androgenic effect. Administration of methyl palmitate or methyl oleate + methyl palmitate combination significantly increases the weight of penis glans and seminal vesicle. However, interestingly, only combination of methyl oleate + methyl palmitate increases the plasma testosterone level, instead of single administration of methyl palmitate [15].

Another research in 2015, illustrates that, administration of the injection of Apilarnil solution increases weight of the seminal glands and epididymis also ejaculate volume, germ cell density, survivability and mobility in boars [16]. This research also corroborates the idea of the usage of Apilarnil as a therapy for testosterone deficiency.

Much of the researches show that Apilarnil has androgenic effect. In addition, scientific experiments significantly determine the active substances in Apilarnil, responsible for the androgenic effect. However, there is no clear explanation on the mechanism of action.

According to a study conducted by Seres, methyl oleate and methyl palmitate is active chemicals in Apilarnil. Moreover, they increase the testosterone levels in castrated rats and they are methyl esters
[15]. Thus, they should be included the androgen production pathway in adrenal cortex or feed-back loop for pituitary. To uncover the mechanism of action, tissue and cell based both in vivo and in vitro experiments should be realized. More complicated scenario is effect of seconder metabolites of methyl oleate and methyl palmitate on androgen production pathway. According to this scenario, illumination of the mechanism gets harder.

\section{Conclusion}

As a result, scientific explanations cannot be sufficient to usage of Apilarnil based drug instead of testosterone replacement therapy. Further studies should be done with Apilarnil about androgenic activity. However, Apilarnil can still be used as testosterone booster food supply for sportsmen or men who are mildly troubled with andropause, and it is also advantageous since it has no known side effects in the literature to date.

\section{References}

1. N.V. Iliesiu, Apilarnil, Editura Apimondia, Bucuresti, Romania, (1991).

2. L.I. Barnutiu, L. A. Marghitas, D. Dezmirean, O. Bobis, C. Mihai, C. Pavel, Physico-Chemical Composition of Apilarnil (Bee Drone Larvae), Lucri Stiinifice-Seria Zootehnie, 59 (2013) 199-202.

3. S. Stângaciu, Apiterapy course notes. Constan a Apiterapy Research Hospital, Bucuresti, Romania, (1999).

4. V.A. Isidorov, S. Bakier, M. Stocki, GC-MS investigation of the chemical composition of honeybee drone and queen larva homogenate, J. Apicul. Sci., 60 (2016) 111-120.

5. R. Margaoan, L.A. Marghitas, D.S. Dezmirean, O. Bobis, V. Bonta, C. Catana, A. Urcan, C.I. Muresan, M.G. Margin, Comparative Study on Quality Parameters of Royal Jelly, Apilarnil and Queen Bee Larvae Triturate, Bull. UASVM Anim. Sci. Biotechnol., 74 (2017) 51-58.

6. R. Balkanska, I. Karadjova, M. Ignatova, Comparative analyses of chemical composition of royal jelly and drone brood, Bulgarian Chem. Comm., 46 (2014), 412-416.

7. S. Bogdanov, Royal jelly, bee brood: composition, health, medicine: review, Bee Product Science, www. bee-hexagon.net. April, 2015.

8. C. Allan, R. McLachlan, Androgen deficiency in men. Medicine Today, 8 (2007) 47-54.

9. R. McLaclan, Androgen (testosterone) deficiency. Andrology Australia Factsheet. (2015) 1-2, Retrieved from www.andrologyaustralia.org/your-health/ testosterone/ 
10. A. Morales, A.J. Bella, S. Chun, J. Lee, P. Assimakopoulos, R. Bebb, I. Gottesman, P. Alarie, H. Dugre, S. Elliott, A practical guide to diagnosis, management and treatment of testosterone deficiency for Canadian physicians, J. Canadian Urol. Assoc., 4 (2010) 269-275.

11. B. Yücel, Z. Açıkgöz, H. Bayraktar, Ç. Seremet, The effects of apilarnil (drone bee larvae) administration on growth performance and secondary sex characteristics of male broilers, J. Anim. Vet. Adv., 10 (2011) 2263-2266.

12. O. Altan, B. Yücel, Z. Açikgöz, C. Seremet, M. Kösoğlu, N. Turgan, A.M. Ozgönül, Apilarnil reduces fear and advances sexual development in male broilers but has no effect on growth, British Poult. Sci., 54 (2013) 355-361.
13. A. Seres, Sexual hormone effects of honeybee (Apis mellifera) drone milk in male and female rats, University of Szeged, 2014.

14. A. Seres, E. Ducza, M. Báthori, A. Hunyadi, Z. Béni, M. Dékány, R. Gáspár, Raw drone milk of honeybees elicits uterotrophic effect in rats: evidence for estrogenic activity. J. Med. Food, 16 (2013) 404-409.

15. A. Seres, E. Ducza, M. Bathori, A. Hunyadi, Z. Beni, M. Dekany, J. Hajagos-Tóth, J. Verli, R. Gaspar, Androgenic effect of honeybee drone milk in castrated rats: Roles of methyl palmitate and methy oleate, J. Ethnopharmacology, 153 (2014) 446-453.

16. K.S. Bolotovna, A. Rustenov, E. Nurlygul, T. Omirzak, U.K. Akhanov, Improving reproductive qualities of pigs using the drone brood homogenate, Biol. Med., 7 (2015) 1-3. 